\title{
THE PHONOLOGICAL SYSTEM OF SASAK DIALECT SPOKEN IN MATARAM; A DESCRIPTIVE STUDY
}

\author{
Yuwanda, Yati \\ English Education Department, Ganesha University of Education \\ e-mail: yuwandlida@gmail.com
}

\begin{abstract}
The research aimed to describe vowels and consonants in Sasak dialect. This research is descriptive qualitative research. The object of this research is the phological system of Sasak dialect about vowel and consonant while the object of this research is people in Mataram city especially in rembige village, Nusa Tenggara Barat. The subject took from the observation technique. They are selected from the characteristics of fluent Sasak dialect. The data collected from three different domains. The domain are family domain, friendship domain and neighborhood domain. The theory to analyze the data was from Miler and Huberman (1984). Instrument collected from observation and recording technique, the result of this research shows that the type of vowels in Sasak dialect are $/ /, / /, / \mathrm{u} /, / \mathrm{e} /, \mathrm{o} / \mathrm{and} / /$. The vowel / $\mathrm{i} / \mathrm{had}$ two allophones namely [ ] and [ i ]. the vowel / e / had two allophones namely [e] and [ ], the vowel /o/ had one allophone namely [o] and the vowel / $\mathrm{u} /$ also had one allophones [ $\mathrm{u}$ ]. There were 18 consonants found in Sasak Dialect, those were: $/ \mathrm{b} /, / \mathrm{c} /, / \mathrm{d} /, / \mathrm{g} /, / \mathrm{h} /, / \mathrm{j} /, / \mathrm{k} /, / 1 /, / \mathrm{m} /, / \mathrm{n} /$, $/ \mathrm{p} /, / \mathrm{q} /, / \mathrm{r} /, / \mathrm{s} /, / \mathrm{t} /, / \mathrm{w} /, / \mathrm{y} /, / \mathrm{y} /$, and $/ \tilde{\mathrm{n}} /$.
\end{abstract}

Keywords:phonology, vowel and consonant, sasak dialect

\section{INTRODUCTION}

In the world, we need to have interaction and relationship with other people because we cannot live alone. When we have interaction with others, we need language, as a tool of our communication. Many linguists agree that there is no all-encompassing definition of language.

However, language is a series of sound produced by said means of a conscious human being (Santoso 1990: 1). Language can be described as a symbolic system in which sounds and meanings are assigned to each other, allowing humans to communicate what we are thinking and how we are feeling and produce it through mouth.Language helps human to communicate in their society. In the normal transfer of information through language, human use language to send vital social messages about whothey are, where they come from, and who they associate with. Without language, human will have difficulty to communicate with each other in their society. People talk about all sorts of things in their lives, discuss various problems, do businesses, show concerns, present ideas, express feeling, and produce various kinds of writings by using language (Seken, 1992). Simply, it can be said that language is one of the most powerful emblems of social behavior. 
As the most important role in communication, language has its own rules. These rules underlie an individual's ability to understand language and formulate language. There are so many languages in this world and it contains the rules of language itself.

People in different area used different language. For example Sasak language which is used by Lombok people in Lombok. Lombok language is used as mean of communication by Lombok people in their daily life. As stated before, each language has its own rules as well as Sasak language. Although people in Lombok used Sasak language, sometimes they possess different dialect depending on the area where they live. Dialect is something that concerns variations which are located regionally or socially (Spolsky 1998:33).Dialect is a variety of a language which is different from others not just in pronunciation but also in such matters as vocabulary, grammar, and word order. Each Sasak language has different dialects that differentiate it with others. Dialect is the easiest way to guess where is someone from which is can be seen from the style of their Sasak language. One of interesting dialect in Sasak language is Sasak language which is used by Lombok people in Mataram city. Mataram city is located in Nusa Tenggara Barat. Most people in Mataram City are Muslim.

EventhoughMataram city surrounded by some other villages where people are Muslim in majority, they live in harmony and cooperatively. They absorb not just Sasak language but also another Sasak culture and tradition, such as, Sasak language, village regulation system, and mixing Moslem arts' culture. People in Mataram city are historically not the descendants of Mataram people but they keep using Sasak language as their mother tongue. They use Sasak language not only as their daily communication tool but also as a communication tools when they held traditional event or religious event. People in Mataram also use formal Sasak language in giving a sermon. Sasak language which is used by Mataram people is different with common Sasak language and it makes Sasak language which is used by Mataram people unique.

Due to the uniqueness of the use of Sasak language in Mataram City, a research on the phonological systems of Sasak Dialect in Mataram city was conducted. As study done by Ouattara (2015), taking into consideration the language speakers, a general purpose of analyzing an undocumented language has somewhat wider ambitions in supporting the linguistic community in keeping their language vital, and also empowering people to value their languages. Through this study, the researcher had the chance to preserve Kecicang Islam dialect in the form of written document by finding out the number of vowels, consonants and diphthongs in the phonological system of Sasak dialect in Mataram and their distribution.

Dialect

Dialect refers to a variety of a language which is different from other not just in pronunciation, but also in such matter as vocabulary, grammar and word order (Roach, 2000). Dialect is a variation of a given language spoken in a particular place or by a particular group of people. Different language communities have certain ways of talking that set them apart from others in case of grammar, pronunciation, vocabulary, and common expression.

According to Spolsky (1998:33) dialect is something that concerns variations which are located regionally or socially. Dialect also means the language variation that comes from a group of users that are relative in numbers, living in one particular place, region or area (Chaer\&Agustina, (1995:83). Dialects vary according to the geographical locations (these are regional dialects) and /or different communities (social dialects) (Panshikar, 2015). 
From the definition above, it can be conclude that dialect is a variety of language used by a group of people from various regions, particular places, and communities in which are each of these group has its own characteristics in using language. It can be seen from the vocabulary, grammar, pronunciation, and word order used by them. Therefore, we can know where are people come from, which community they are.

Phonology

Phonology is the study of the sound systems found in human languages (Carr, 2008). Therefore, phonological system is the number of phonemes that exists a language and how they are organized. Phonology is the study of the sounds system of language (Hyman, 1975). As stated by Gimson (1970), phonology is the study of concrete phonetic characteristic such as articulatory, auditory, and acoustic of sounds used in language. As the study done by Baso (2007), Phonology is a subfield of linguistics which studies the sound system of a specific language or a set of language. From those definitions, it can be conclude that phonology is the study of speech sounds structure and function in languages.

Basically, phonology course has two main branches, that is; Phonetics and Phonemics. Phonetics is the study of vocal sounds which is limited to the study of speech sound by means of auditory judgment and analysis in terms of articulators' movement (Pike, 1975). Articulatory phonetics is the study about the production of speech-sounds by means of the organs of speech and acoustics phonetics is the study about the nature of sounds which we hear, the characteristics of the transmission phase of these sounds, and the way in which these sounds are perceived by a listener (Roediyanto: 1983). Meanwhile, phonemics is the study of the structural arrangement of sounds segments in relation to units of sound in a particular language. Both, phonetics and phonemics has close relationship. Phonetics and phonemics work together to produce language in order to make the speaker read and speak the language easily.

Roediyanto (1983), mentions that there are two main purposes of studying phonology, for practical purposes and theoretical purposes. In terms of practical purposes there are three purposes, namely: to get the skill in both hearing and producing foreign sounds, to know the sound-system of both the native and the foreign language as the basis of making a comparison and for further analysis, and to be able become a good models especially in pronunciation. Meanwhile, in terms of theoretical purposes there are two purposes, namely: to study technique of describing sounds in terms of the movement of the vocal appertains and for writing them in terms of articulatory formulas (Phonetics alphabet), and also to get a solid foundation of the sounds system of language being studied

Phoneme

As study done by Salcedo (2010), a phoneme is a class of soundsthat is one element in the sound system of a language having a character set of interrelationships with each of the other elements in that system. According to Roach (1983), Phoneme is a small number of regularly used sounds (vowel and consonant). In addition, Hornby (1989) stated that phoneme is any one of the set of smallest units of speech in a language that distinguish one word from another.

From the definition above, it can be concluded that phoneme is the smallest unit of speech distinguishing one word (or word element) from another, as the element $p$ in "tap," which separates that word from "tab". 
Vowel

Jones (1972) defines a vowel as a voiced sound during the production of which the air stream passes freely through the larynx and the upper cavity. According to Roediyanto (1963), during the vowel production the breath is flow out the mouth without closing any part of mouth or throat, but there is a chance that lips may move in order to create a correct sound. Among 26 letters in English, 5 of them are vowels (a, i, $\mathrm{u}, \mathrm{e}, \mathrm{o}$ and sometimes $\mathrm{y}$ ). In order to classify a vowel, there are five kinds of classification that are use, those are, based on tongue position, the length, the rounding, nasality, and diphthongs.

Consonant

A consonant is a speech sound during the production of which their air stream is obstructed either completely or partially between the larynx and the outside air (Gimson, 1990). The consonant is formed by using the lips, teeth, tongue, and palate. In English, there are 26 letters, in which 21 of them are consonant (b, c, d, f, g, h, j, k, 1, m, $\mathrm{n}, \mathrm{p}, \mathrm{q}, \mathrm{r}, \mathrm{s}, \mathrm{t}, \mathrm{v}, \mathrm{w}, \mathrm{x}, \mathrm{y}, \mathrm{z}$ ). All consonants are produced by entirely or almost entirely stopping the airstream coming from the lungs. When we almost entirely stop the airstream we force it through such a narrow opening that the airflow at that point is turbulent and noisy (Delahunty\& Garvey, 2010). There are three ways to classify consonant, which commonly called as VPM (Voice, Place, and Manner).

Voicing is a process in which the edges of the vocal folds (two thick flaps of muscle inside the larynx) touch the other, air passing through the glottis will usually cause vibration. In English the following consonants are voiced, b, d, g, v, ð, z, 3, 1, r, j, $\mathrm{w}, \quad, \mathrm{m}, \mathrm{n}, \mathrm{y}$. Meanwhile, the following ones are voiceless, $\mathrm{p}, \mathrm{t}, \mathrm{k}, \mathrm{f}, \theta, \mathrm{s}, \mathrm{h}$, .

\section{METHOD}

This chapter presents a discussion on the method of investigation that was used in this study such as: research design, subjects of the study, objects of the study, method of data collection, research instrument, procedures of data collection, and data analysis.. It includes the subject of the study, research design, and informant sample.

In order to get an authentic data, the researcher selected informants based on four domains. Those domains were family, friendship, neighborhoods, and religion.

1)The first domain is family. The researcher found the information from one or more families in Mataram city. Then, the researcher recorded the conversation in that family, the conversation here about how the conversation was done by the member of family. It can be seen from how father talked to his wife, children talked to the father or mother and children talked to his/her brother.

2) The second one is friendship. In this domain, the researcher found the information from friendship which existed in Mataram city. It was the same as the family domain in order to get the information, but in this case the researcher only observed and recorded what kind of the conversation's used between the members of friendship in Maratam city

3) The third domain is neighborhoods. This category also had the same way in order to get the information with two domains before. However, this domain focused on how the neighbor interact each other.

There were some steps that had been done by the researcher in doing this study, they were:

International Journal of Language and Literature | 68 
1) The researcher prepared the instrument that was used to collect the data which consisted of word list, phone recorder and interview guide.

2) The researcher fulfilled the administrative permission to conduct the research in Mataram city

3) After being given the permission, the researcher did small talk or conversation with the staff in order to know the informant expectation in this study. In this case, the researcher asked for guidance to choose appropriate family to be used as the informant of this research.

4) After knowing the family, the researcher visited them. Then, the researcher told the purpose and made a kind of good relationship with the informants

In this research, the main instrument was the researcher. It was because the researcher was the one who determined whether the research continued or not. The other instruments that used for collecting the data in this research were:

1) Recorder, it was used to record all conversations and pronunciation of the Mataram city effectively.

2) Interview Guide, it was used as a tool in order to help the researcher in doing interview process.

\section{FINDING AND DISCUSSION}

There was 24 phonemes found in Sasak dialect in Mataram city. Those phonemes can be classified as: vowel and consonants. Most of the phonemes exist in three positions: initial, The Vowel System of Sasak Dialect

Sasak Dialect has 10 vocoids, namely [ ], [i], [ ], [u], [ ], [e], [ ], [ ], [o] and [ ]middle, and final. Further explanation can be seen in the following section.

a. The Vowel Phonemes Distribution of Sasak Dialect

From the six phoneme that found in Sasak dialect, there were three phonemes that completely distributed, which were / e /, / o / and / a /. Here, vowel did not have a complete distribution. While, vowel $/ \mathrm{u} / \mathrm{did}$ not look complete. It was because allophone / / only appeard in the middle position. So do the allophone / / in phoneme /i/ which is not completely distributed because only appear in the middle position

b. The Distribution of Consonant of Sasak language

From the 18 consonants that existed in Sasak Dialect, there were only 12 consonants had complete distribution and other 7 consonants had incomplete distribution, they were: phoneme $/ \mathrm{c} /, / \mathrm{j} /, / \mathrm{w} /, / \tilde{\mathrm{n}} /, / \mathrm{h} /$ and $/ \mathrm{y} /$. The clearer explanation can be seen as follows:

a) phoneme $/ \mathrm{c} /, / \mathrm{j} /, / \mathrm{w} /, / \tilde{\mathrm{n}} /$, and $/ \mathrm{y} /$ only appeared in the initial and the middle position.

b) Phoneme / $\mathrm{h} /$ only appeared in the initial and the final position.

From the findings of the study, there were 25 phonemes found in SasakDialect spoken in Mataram city. Those phonemes can be classified as: vowel and consonants. Most phonemes existed in three positions: initial, middle, and final. Several phonemes were not accupied in complete distribution. Moreover. Researcher compared between something that has been found with another finding related to phonology system.

a. Vowel

The researcher found 6 vowel in Sasak Dialect. Those were / /, / i /, / /, / e/, / o / and $/ \mathrm{a} /$. The vowel / $\mathrm{i} / \mathrm{have}$ one allophones which is $/ \mathrm{I} /$. So does the vowel / $\mathrm{u} /$ also 
have one allophones / /. The same with guntara (2009:40) that found vowel / /, / i /, / $\mathrm{u} / \mathrm{s} / \mathrm{e} / \mathrm{s} / \mathrm{o} /$ and / $\mathrm{o} /$ in Tigawasadialect system. The same with another research EviRyaSanti (2010:46) who researched about penolokan dialect phonological system and also Dina ugiyanti (2010:45) who researched about madenan dialect phonological system.

From the six phoneme that were found in Sasak dialect, there were three phonemes that completely distributed, namely / /, / /, / o / and / o /. / u /. While in Tigawas dialect, there are 5 vowel that had complete distribution process. Only vowel that have incomplete distribution. It was the same with in Sasak dialect. Furthermore, it was related to Balinese vocabulary. If alphabet A is I n last word, usually will be pronounced as ə (Guntara, 2009).

b. Consonant

In Sasak Dialect, the researcher found 18 consonants, namely: /b/, /c/, /d/, /g/, /h/, $/ \mathrm{j} /, / \mathrm{k} /, / \mathrm{l} /, / \mathrm{m} /, / \mathrm{n} /, / \mathrm{p} /, / \mathrm{r} /, / \mathrm{s} /, / \mathrm{t} /, / \mathrm{w} /, / \mathrm{y} /, / \mathrm{y} /$, and $/ \tilde{\mathrm{n}} /$. It was the same with Guntara's research (2009) and Eviryasanti (2010). The different things are in the consonant distribution process itself. In Krisnayanti's research, from the 19 consonants that existed in Penelokan Dialect, there were only 7 consonants had complete distribution and other 12 consonants had incomplete distribution, they were: phoneme $/ \mathrm{c} /, / \mathrm{j} /, / \mathrm{w} /, / \tilde{\mathrm{n}} /, / /$ and $/ \mathrm{y} /$. Phoneme $/ \mathrm{c} /, / \mathrm{j} /, / \mathrm{w} /, / \tilde{\mathrm{n}} /$, and $/ \mathrm{y} /$ only appeared in the initial and the middle position. Phoneme / / only appeared in final position. While in Sasak dialect, from the 18 consonants that existed in Sasak Dialect, there were only 12 consonants had complete distribution and other 6 consonants had incomplete distribution, they were: phoneme $/ \mathrm{c} /$, $/ \mathrm{j} /, / \mathrm{w} /, / \tilde{\mathrm{n}} /, / \mathrm{h} /$ and $/ \mathrm{y} /$. It can be seen in the following explanation. Phoneme $/ \mathrm{c} /, / \mathrm{j} /, / \mathrm{w} /$, $/ \tilde{\mathrm{n}} /$, and $/ \mathrm{y} /$ only appeared in the initial and the middle position. Phoneme $/ \mathrm{h} /$ only appeared in the initial and the final position.

\section{CONCLUSION}

Based on the finding and discussion stated in the chapter IV, it can be concluded that:

1. There were 25 phonemes founded in Sasak Dialect formed as vowel and consonant. Those were / /,/ i /,/ u/, / e /, / /, / a /, /b/, /c/,/d/,/g/,/h/,/j/, /k/, /l/, $/ \mathrm{m} /, / \mathrm{n} /, / \mathrm{p} /, / \mathrm{q} /, / \mathrm{r} /, / \mathrm{s} /, / \mathrm{t} /, / \mathrm{w} /, / \mathrm{y} /, / \mathrm{y} /$, and $/ \tilde{\mathrm{n}} /$.

2. The kinds of phonemes found in Sasak Dialect were classified into vowel and consonant

a. Vowel

Sasak dialect had six vowel, namely: / /, / i /, / u /, / e /, / o / and / / /. The vowel / i / had two allophones which is / i / and / /. The vowel / e / had two allophones namely / e / and / /. The vowel / o / had two allophones namely / $\mathrm{o} /$ and / / and the vowel / $\mathrm{u} /$ also had two allophones namely / / and / $\mathrm{u} /$.

b. Consonant

There were 19 consonants found in Sasak Dialect, those were: /b/, /c/,/d/, /g/, $/ \mathrm{h} /, / \mathrm{j} /, / \mathrm{k} /, / 1 /, / \mathrm{m} /, / \mathrm{n} /, / \mathrm{p} /, / \mathrm{q} /, / \mathrm{r} /, / \mathrm{s} /, / \mathrm{t} /, / \mathrm{w} /, / \mathrm{y} /, / \mathrm{n} /$, and $/ \tilde{\mathrm{n}} /$. From the 19 consonants that existed in Sasak Dialect, there were only 8 consonants had complete distribution and other 11 consonants had incomplete distribution, they

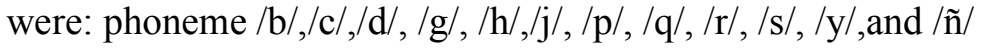

This study focused on Sasak Dialect phonological process. The major focus of this study was discuss about phonemes (vowel and consonant) in Sasak dialect itself. This 
study is important for people in Sasak because it can be the source to know about their own phonological system. The study about dialect is an interesting thing to be done because not many researcher has done about this study.

Several things that has been not discussed in this study are Sasak dialect system affix and comparison between Sasak phonological system in Mataram with North Lombok or South Lombok. It is because Mataram is in the middle of Lombok and South Lombok. If it is recited from another perspective like sociolinguistics, pragmatics and sintax, Sasak dialect has so many things to be recited.

\section{REFERENCES}

Gimson, A.C. (1970). An Introduction to the Pronounciation of English. England: J.W.Arrowsmith Ltd.

Roediyanto, Razak. (1983). A course in phonology. FKIP Udayana University Singaraja: Unpublished

Spolsky, B. (1998). Sociolinguistics.Oxford: OUP. Retrieved from http://www.academia.edu/8972723/Style and Register onmonday, 15 Agustus 2015.

Spolsky, B (1998). Sosiolinguistics: Oxford Introduction to Language Study. Oxford University Press.

Schanes, S. A. (1973). Generative Phonology. New Jersey: Prentice-Hall, Inc.

Wiranata, W. Budasi, G. Marjohan, A. (2013). The Phonological System OfTambakan Dialect: A Descriptive Qualitative Study. Singaraja: Universitas Pendidikan Ganesha

Ugiyanti. (2010). The phonological system of Madenan Dialect (MD). Unpublished Thesis: Universitas Pendidikan Ganesha.

Santi. (2010). The study about the phonological system of Penelokan Dialect (PD). Unpublished Thesis: Universitas Pendidikan Ganesha. 